Human and Animal Health

Vol.60: e17160391, January-December 2017 http://dx.doi.org/10.1590/1678-4324-2017160391 ISSN 1678-4324 Online Edition

\title{
Thymbra Spicata Var. Intricata Induces Mesenchymal Stem Cell Proliferation and Osteogenic Differentiation
}

\author{
Ayseqül Mendi ${ }^{1 *}$, Beyza Gökçınar Yağcı ${ }^{2}$ Mustafa Kızıloğlư ${ }^{3}$, Nurdan Saraç ${ }^{4}$, Aysel Uğur $^{1}$, \\ Derviş Yılmaz ${ }^{3}$, Duygu Uçkan². \\ ${ }^{1}$ Gazi University, Faculty of Dentistry, Department of Medical Microbiology, Ankara, Turkey; ${ }^{2}$ Hacettepe \\ University, PEDI-STEM Center for Stem Cell Research and Development, Ankara, Turkey; ${ }^{3}$ Gazi University, \\ Faculty of Dentistry Department of Oral and Maxilofacial Surgery, Ankara, Turkey; ${ }^{4}$ Mugla Sitki Kocman \\ University, Faculty of Sciences, Department of Biology, Mugla.
}

\begin{abstract}
A natural agent that maintains mesenchymal stem cell (MSCs) viability, promotes osteogenic differentiation while modulating the immunological response could achieve success in regeneration during healing and may also prevent bone resorption and improve regeneration. We aimed to demonstrate that a Thymbra spicata var. intricata extract could induce proliferation, differentiation, and modulate the immune responses of mesenchymal stem cells (MSCs). Using xCELLigence, a real-time monitoring system, we obtained a growth curve of MSCs. A dose of $10 \mu \mathrm{g} / \mathrm{mL} \mathrm{was}$ the most efficient concentration for vitality. Osteogenic differentiation and antiinflammatory activities were determined by using an ELISA Kit to detect early and late markers of differentiation. The Osteonectin (ON, early osteogenic marker) level decreased while the Osteocalcin (OCN, late osteogenic marker) level increased in the T. spicata var. intricata treated group, suggesting that $T$. spicata var. intricata may accelerate osteogenic differentiation. Reduced level of the IL-6 cytokine in repsonse to TNF- $\alpha$ was evident. T. spicata var. intricata could be a promising osteogenic inducer in dentistry and could be used safely in biocomposites or scaffold fabrications.
\end{abstract}

Key words: mesenchymal stem cell, osteogenic differentiation, T. spicata var. intricata, bone regeneration

\footnotetext{
Author for correspondence: aysegulmendi@gmail.com
} 


\section{INTRODUCTION}

Dental pulp mesenchymal stem cells (DP-MSCs) are a type of mesenchymal stem cell (MSCs) found in the cell-rich zone of the pulp tissue of teeth ${ }^{1}$. DP-MSCs have a strong self-renewal ability and the potential for multi-directional differentiation, which gives them great therapeutic potential for repairing damaged and/or defective tissue $^{2}$.

The presence and maintenance of alveolar bone is tooth dependent. After tooth extraction, the alveolar bone is slowly resorbed down to the body of the jaw bones. In cases of complete tooth loss, there is progressive bone resorption, which can result in extensive atrophy of the jaw bones and lead to major clinical challenges for implant placement and the construction of dental prostheses ${ }^{3}$. Even without therapeutic intervention, the periodontium can exhibit a significant capacity for regeneration. However, such endogenous activity has limited capacity for periodontal regeneration. In addition, the impairment of bone formation increases in patients with osteoporosis and diabetes mellitus and related conditions ${ }^{4}$. We hpothesize that a natural agent that maintains MSCs viability, promotes osteogenic differentiation while modulating the immunological response could achieve success in regeneration during healing and may also prevent bone resorption and improve regeneration.

Thymbra spicata L. a wild medicinal plant of Eastern Mediterranean countries; is represented by namely $T$. spicata var. spicata and $T$. spicata var. intricata in Turkey $^{5}$. The main componenet, Carvacrol, predominates $(>80 \%)$ in the essential oil and demonstrated significant level of anti-hypercholesterolaemic and antioxidant activities in mice ${ }^{6}$. Also carvacrol has been observed with many diverse physiological actions, such as antibacterial ${ }^{7}$, antiinflammatory ${ }^{8}$. Dried herbal parts of the plant are used as herbal tea, and in folk medicine to treat asthma, colic, bronchitis, coughs, diarrhoea and rheumatism in various parts of Turkey ${ }^{9}$. It was important for our study that dried T. spicata herb contain $1925.7 \mathrm{mg} / \mathrm{kg}$ Ca since experimental evidence clearly indicates the key role of $\mathrm{Ca}^{2+}$ in osteoinduction ${ }^{10,11}$.

Although various physiological activities of $T$. spicata have been demonstrated, its link to osteogenic differentiation of mesenchymal stem cells has never been explored. In the present study, we hypothesized that $T$. spicata var. intricata could maintain the viability of DP-MSCs, induce promote their osteogenic differentiation, which may enable the successful regeneration of hard tissues. We also used bone marrow derived MSCs as control.

\section{MATERIALS AND METHODS}

\section{Extraction of Plant Samples}

T. spicata var. intricata flower buds were purchased from the local market in Mugla, Turkey. The air-dried plant samples were extracted with ethanol (Merck, Taufkirchen Germany) using a Soxhlet apparatus. The extracts were evaporated and stored in sterile opaque glass bottles under refrigerated conditions until use. The dried extract was prepared in DMEM-LG with $10 \%$ foetal bovine serum (FBS) (Invitrogen, Carlsbad, Calif., USA), 1\% L-glutamine (Sigma, Taufkirchen Germany) and 1\% Penicillin-Streptomycin (Invitrogen, Carlsbad, Calif., USA) for the studies.

\section{Isolation and Culture of Dental Pulp Mesenchymal Stem Cells}

Human dental pulp tissue was obtained from patients (15-20 years of age) who were undergoing extraction of their third molars for orthodontic reasons at the Department of Oral and Maxillofacial Surgery, University of Gazi, Ankara. All patients provided 
informed consent (Ethics Commit. Rep. No: G.Ü. B30.2. GÜN 0.21.71.00). After the tooth surfaces were disinfected, the teeth were mechanically fractured, and the dental pulp was gently isolated with forceps. The pulp tissue was rinsed in $\alpha$-MEM supplemented with $2 \mathrm{nM}$ L-glutamine, $100 \mathrm{U} / \mathrm{mL}$ penicillin, $100 \mu \mathrm{g} / \mathrm{mL}$ streptomycin and $10 \%$ fetal bovine serum (FBS, Invitrogen) (hereafter referred to as the MSC culture medium), after which it was minced into fragments of 1 to $2 \mathrm{~mm}^{3}$. The tissue fragments were cultured in T75 Nunc plates in the MSC culture medium at $37^{\circ} \mathrm{C}$ in a humidified atmosphere containing $5 \% \mathrm{CO}_{2}$. Human BM-MSCs were a kind gift from Hacettepe University Center for Pediatric Stem Cell and Research and Development. BM-MSCs were suspended at a concentration of $1 \times 10^{6}$ cells $/ \mathrm{mL}$ in MSC culture medium. The culture media was changed every 2 to 3 days, and the cell cultures were monitored regularly with an inverted microscope (Olympos CKX41, Tokyo, Japan). Upon reaching 70-80\% confluence, the cells were harvested with $0.05 \%$ Trypsin/EDTA (Sigma, Taufkirchen Germany) and sub-cultured for further experiments.

\section{Immunophenotypic Analysis}

The culture-expanded adherent cells were analysed by flow cytometry (BD FACSAria, USA). The antibody panel included CD29- FITC (e-bioscience, USA); CD73-PE (BD, USA), CD 90-PE (BD, USA), CD44-PE (e-bioscience, USA) as mesenchymal stromal markers, as well as their isotype controls. CD45-FITC (BD, USA); CD14-PE (BD, USA); and CD34-FITC (BD USA) were used as haematopoietic markers to exclude cells of haematopoietic origin. The relative frequencies of the cells that expressed the respective surface markers were analysed using FACS Diva software 6.0.0 (BD) by acquiring 10,000 events for each sample.

\section{Effect Of T. spicata var. intricata on Proliferation of the MSCs Using the xCELLigence System}

Initially we examined the proliferation of DP-MSCs in a 24 well culture microplate seeded at a density of $5000 \mathrm{cell} / \mathrm{cm}^{2}$. DP-MSCs were cultured with different concentrations $(1,3,5,10,25,50,75$, and $100 \mu \mathrm{g} / \mathrm{mL})$ of $T$. spicata var. intricata up to the control group had $90 \%$ confluency. Cells were counted by trypan blue method and the three concentrations which induced the cell number was selected for xCELLigence analysis (data not shown). The xCELLigence system was used according to the manufacturer's instructions ${ }^{12}$. Briefly, the E-plate 96 was connected to the xCELLigence system and verified in the cell culture incubator to ensure that proper electrical contacts were established, and the background impedance was measured. Subsequently $100 \mu \mathrm{l}$ of MSCs culture media containing 5, 10 and 25 $\mu \mathrm{g} / \mathrm{mL} T$. spicata var. intricata extract and standart culture media as control were added into each well of E-plate 96. Meanwhile, the cells were resuspended (5000 cells $/ \mathrm{cm}^{2}$ ) in MSC culture media for their concentration. $100 \mu \mathrm{l}$ of each cell suspension was added to each well, in order to determine effect of T. spicata var. intricata extract on cell proliferation. Cell growth and proliferation were monitored every $30 \mathrm{~min}$ for up to $290 \mathrm{~h}$. The growth curve, cell index, and doubling time (DT) values were determined.

\section{Effect of T.spicata var. intricata on MSCs Differentiation}

The concentration that decreased the doubling time and increased the proliferation was selected based on the results from the xCELLigence system analysis. The selected concentration was added to the osteogenic and adipogenic differentiation media $^{13}$. The images were obtained with a CKX41 digital imaging microscope (Olympus, Tokyo, Japan). The secreted Osteocalcin (OCN) and Osteonectin (ON) levels in the supernatants were assessed using an ELISA kit according to the 
manufacturer's instructions (R\&D Systems, Inc. Minneapolis). The limits of detection for the ELISA were 1.2 to $75 \mathrm{ng} / \mathrm{mL}$ for $\mathrm{OCN}$ and 1.56 to $50 \mathrm{ng} / \mathrm{mL}$ for ON.

\section{Determining the Immunomodulatory Activities}

DP- and BM-MSCs were plated at a density of $5000 \mathrm{cell} / \mathrm{cm}^{2}$ in $96-$ well culture plates and allowed to attach overnight. The cells were pretreated with $10 \mu \mathrm{g} / \mathrm{mL} T$. spicata var. intricata extract for $1 \mathrm{~h}$, and $10 \mathrm{ng} / \mathrm{mL}$ TNF- $\alpha$ were then added. After 24 $\mathrm{h}$, the cell culture supernatants were collected and stored at $-80^{\circ} \mathrm{C}$ for use in the IL-6, IL-10 ELISAs, according to the manufacturer's instructions. The ELISA limits were 0,052-0,118 pg/mL for IL-6 and 0,39-25 pg/mL for IL-10. Media alone, with TNF$\alpha$, and with $T$. spicata var. intricata were included as controls.

\section{Statiscal Analysis}

All calculations were performed using the RTCA integrated software of the xCELLigence system. The RTCA software fits the curve of the selected sigmoidal dose response equations to the experimental data points. The data are presented as the mean $(\mu \mathrm{g} / \mathrm{mL}) \pm \mathrm{SD}(\mathrm{n}=4)$. For the proliferation experiments, the statistical analysis was performed using one-way analysis of variance (ANOVA) $(p<0.05)$.

\section{RESULTS}

\section{Identification of MSCs}

The common MSC markers (CD29, CD73, CD44, and CD90) were constitutively positive $(>95 \%)$ and the hematopoietic markers (CD14, CD34, and CD45) were negative $(>95)$ in all samples tested, indicating a mesenchymal origin of the cells (Figure 1).
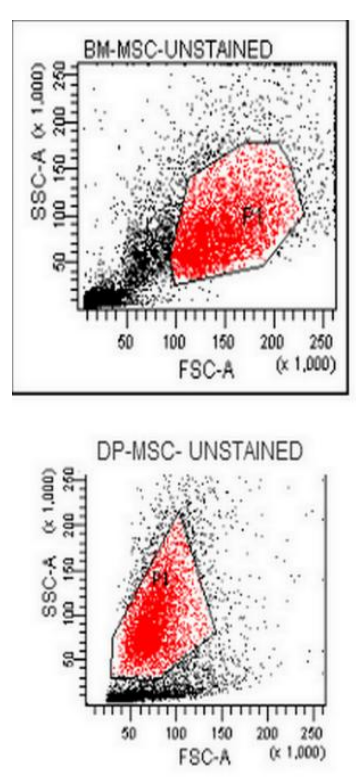

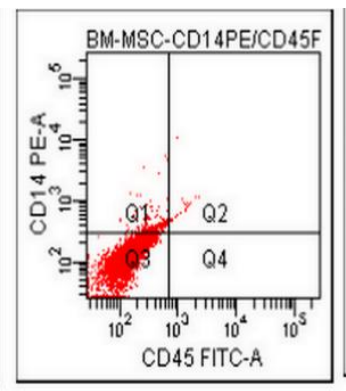

DP-MSC- CD $45 / C D 14$

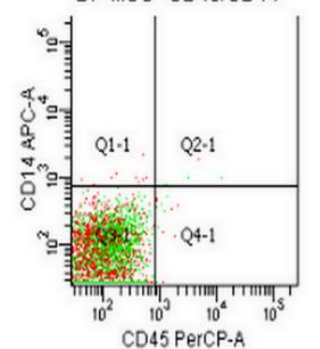

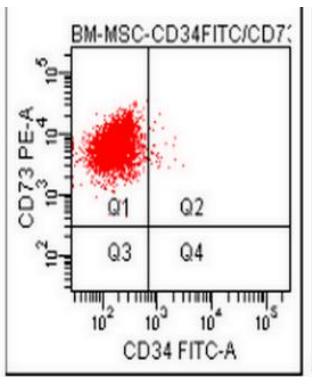

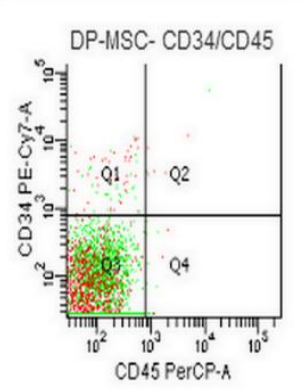

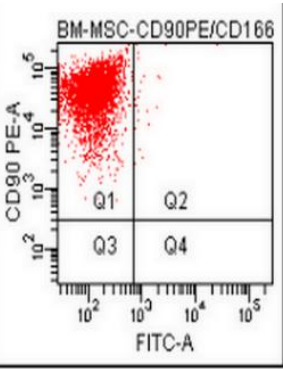
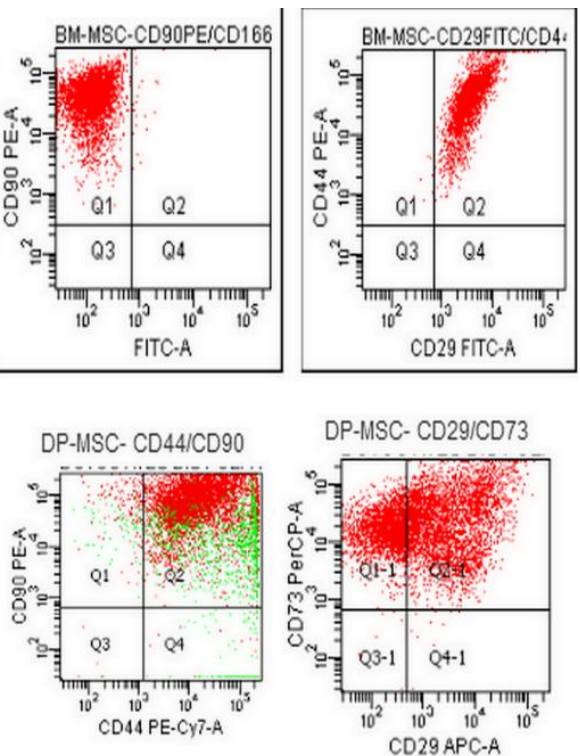

Figure 1: Surface markers of DP-MSCs and BM-MSCs

\section{xCELLigence Assays}

Trypan blue assay showed that the concentrations between $1-5 \mu \mathrm{g} / \mathrm{mL}$ and $25-100$ $\mu \mathrm{g} / \mathrm{mL}$ reduced the viability of DP-MSCs. $10 \mu \mathrm{g} / \mathrm{mL}$ was found close to the Control group (data not shown). We selected 5, 10, and $25 \mu \mathrm{g} / \mathrm{mL}$ for the xCELLigence analysis system (Figure 2). The xCELLigence analysis showed that the growth 
curves of the DP-MSCs and BM-MSCs treated with T. spicata var. intricata were slightly lower than the growth curve of the controls, but they were close to each other for the culture period except $5 \mu \mathrm{g} / \mathrm{mL}$. We determined the cell indexes for the time intervals of the lag, log, and plateau phases using the growth curve. xCelligence assay showed that cells treated with $T$. spicata var. intricata had lower adhesion, but similar viability when compared with control cells. The doubling time (DT) was reduced at $10 \mu \mathrm{g} / \mathrm{mL}$ in DP-and BM-MSCs. Thus, T. spicata var. intricata could be a good proliferation inducer. The $\mathrm{IC}_{50}$ value was found $7,7 \mu \mathrm{g} / \mathrm{mL}$ for DP-MSCs and $17 \mu \mathrm{g} / \mathrm{mL}$ for BM-MSCs at $290 \mathrm{~h}$.
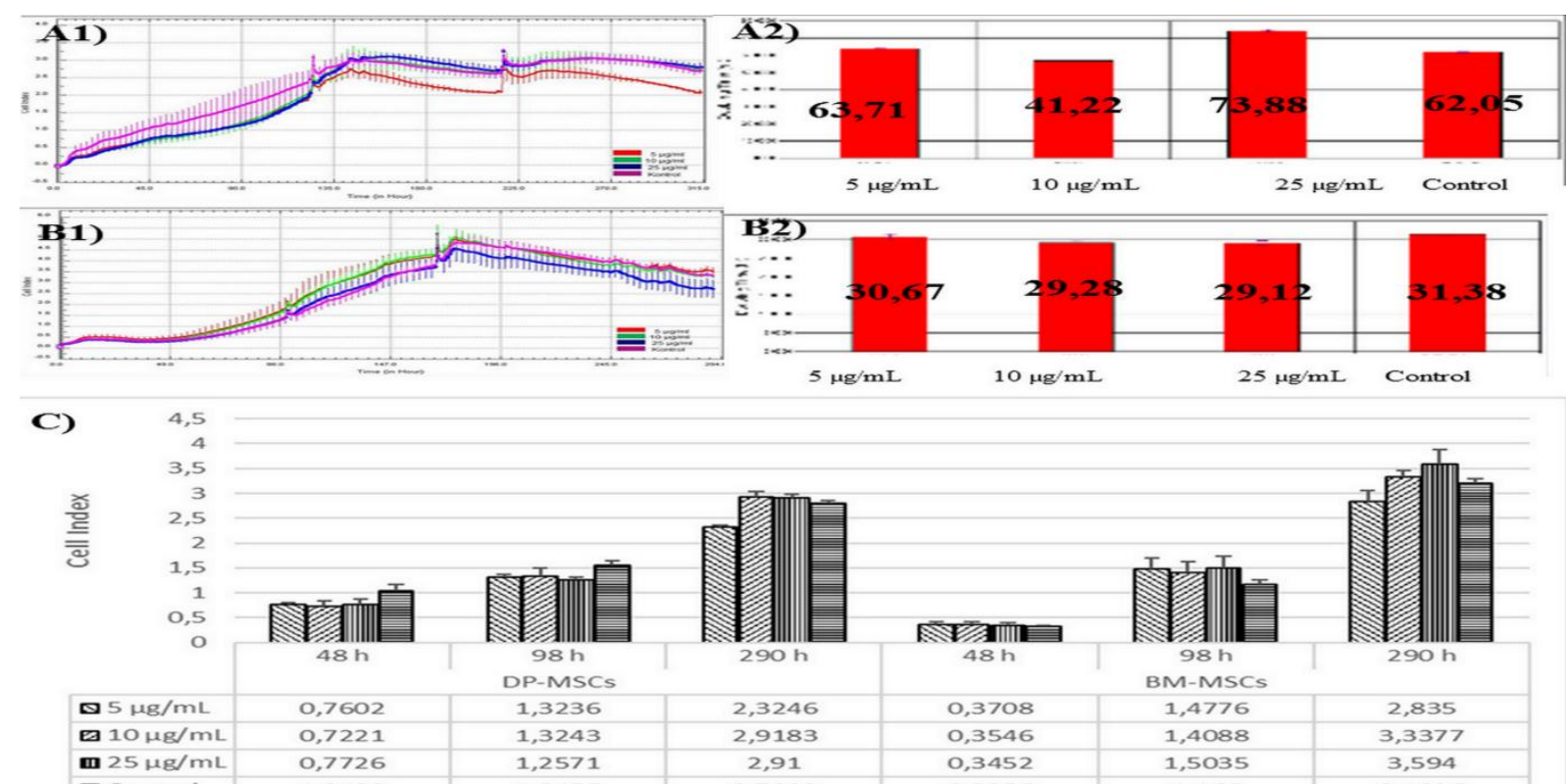

Figure 2: xCELLigence analysis of DP-MSCs and BM-MSCs. Growth curve of the cells. a1) DP-MSCs, b1) BMMSCs; doubling time of the DP-MSCs (a2) and BM-MSCs (b2) and the cell indexes at lag mid log, and stationary phases (c) of the cells were determined.

\section{Differentiation Assays of MSCs}

Subsequently, the characteristics features of the cells were studied. (Figure 3). Adipogenic differentiation exhibited a quite difference in DP-MSCs treated with $T$. spicata var. intricata. Approximately $20 \%$ of the cells became rounder; however, no lipid droplets were observed in DP-MSCs. In contrast to adipogenic differentiation, the DP-MSCs underwent rapid osteogenic differentiation. Calcium granules similar to bone nodules were seen in BM-MSCs. T. spicata var. intricata treated DP- and BM-MSCs showed more osteogenic differentiation than the control cells. We also determined the levels of the ON and OCN osteogenic markers. 

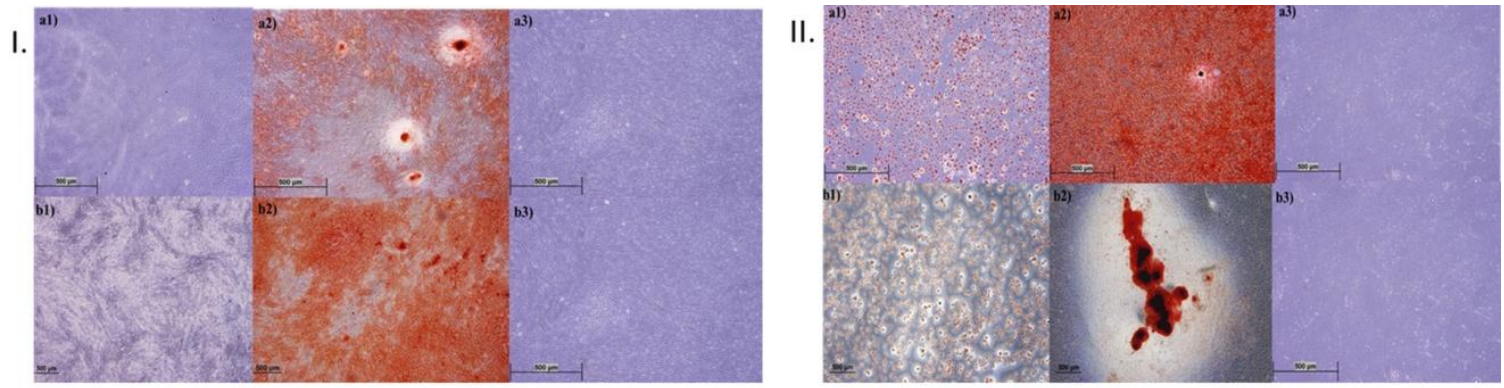

III.

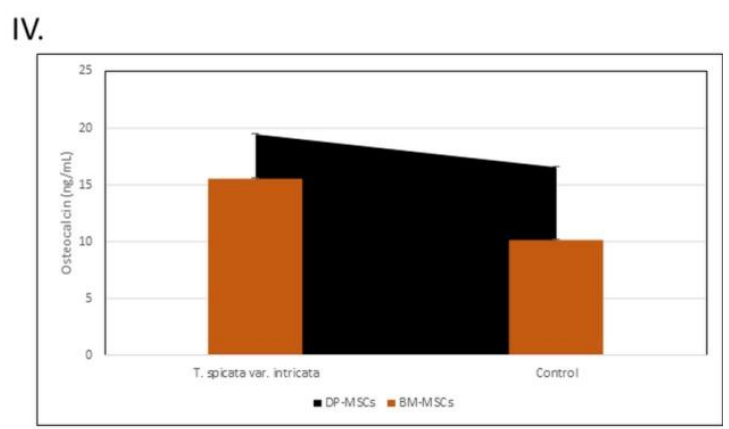

Figure 3: Differentiation potential of DP-MSCS (I) and BM-MSCS (II). adipogenic differentiation was not shown in DP-MSCs (I.a1) while BM-MSCs (II.a1) were well differentiated. Although T. spicate var. intricata lead to cell morphology changes in adipogenic differentiation of DP-MSCs (I.b1), it was not occured like BM-MSCs (II.b1). Osteogenic differentiation was observed in DP-MSCs (I.a2) and BM-MSCs (II.b2). The extract of T. spicata var. intricata induced both DP-MSCs (I.b2) and BM-MSCs (II.b2) osteogenic differentiation (4x, Olympos CKX41, Japan). Osteonectin (III) and osteocalcine (IV) levels are calculated from supernatant of culture medium.

Determining the Preventive Effect of $T$. spicata var. intricata on the Inflammatory Response of MSCs Following TNF- $\alpha$ Stimulation

Figure 4 shows the antiinflammatory activities of $T$. spicata var. intricata. Obtained data showed an antinnflammatory and immunomodulatory effect of the extract.

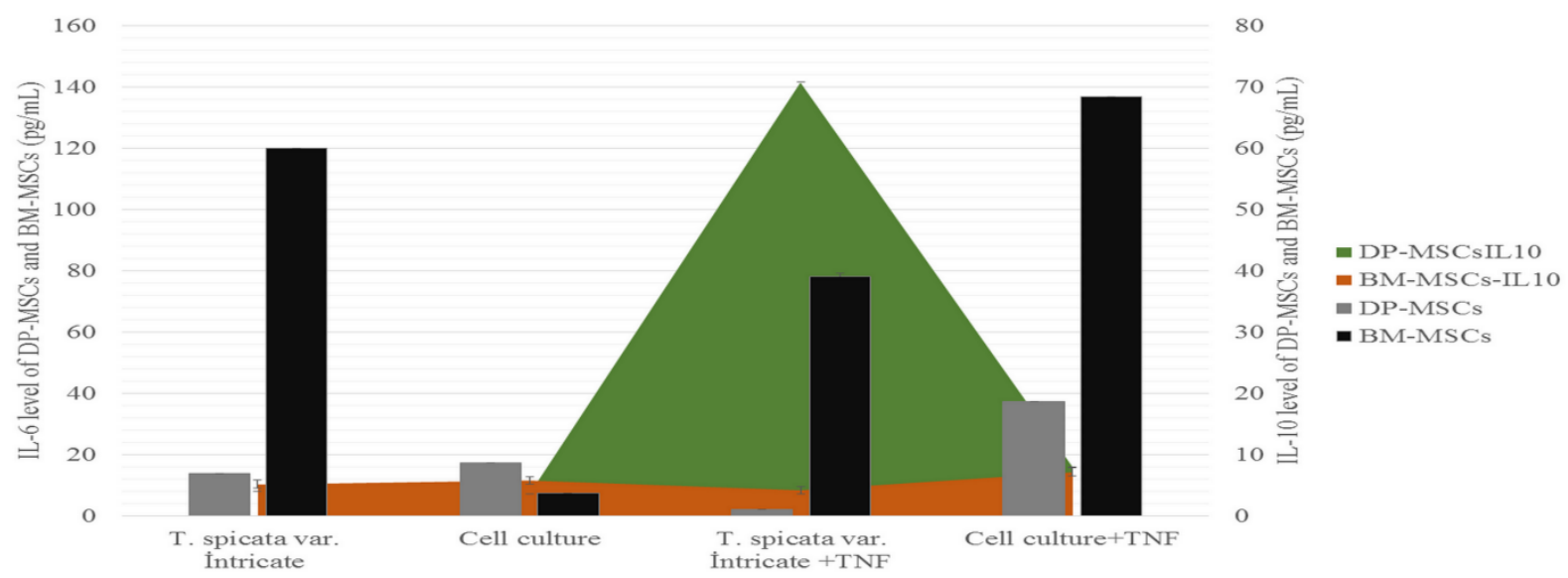

Figure 4: IL-6 (a) and IL-10 (b) level determined in the culture supernatant of DP and BM-MSCs.

\section{DISCUSSION}

In the present study, we demonstrated that $T$. spicata var. intricata extract can induce proliferation, differentiation, and modulate the immune responses of DP- and BMMSCs. Initially, we aimed to define the effective concentration of $T$. spicata var. intricata. Using the xCELLigence system, we obtained a growth curve for MSCs 
which provides information on three parameters: the lag phase before cell proliferation is initiated after subculture, the DT in the middle of the exponential growth phase, and the terminal density ${ }^{2}$. The lag phase is the time period when the cells are recovering from trypsinization, synthesizing new extracellular matrix and cytoskeleton, and adapting for attachment, spreading and re-entering the cell cycle. Cells do not divide in the lag phase ${ }^{13}$. We could conclude that $T$. spicata var. intricata reduced the adhesion of DP-MSCs at 48h and 98h whilst BM-MSCs were adhered and proliferated more than the Control group. Ideally, towards the end of the $\log$ phase, the culture becomes confluent and its growth rate reduces, and in some cases, cell proliferation ceases. At this stage, the culture enters the plateau, or stationary phase, in which cell division is balanced by cell loss. DP-MSCs were still alive where BM-MSCs began to reduced their cell number. Also T. spiacata var. intricata reduced the DT of DP- and BM-MSCs suggesting that it would be an advantage in if used as a filling material scaffold in dental therapies.

Oriental medicine practices are primarily based on personal experience, which often result in unknown mechanisms and difficulties in dose specification. We used a realtime monitored system, xCELLigence, to determine the effective concentration. The xCELLigence system is much more sophisticated than other conventional endpoint, cell-based assays. Real-time and continuous monitoring enable the label-free assessment of cell proliferation, viability, and cytotoxicity by showing the physiologic state of the cells and eliminating expensive reagents that are used in conventional cell analyses ${ }^{14}$.

The osteogenic differentiation potentials of DP-MSCs in vitro and in vivo have been well documented in a variety of studies ${ }^{2,15}$. Adipogenic differentiation was not seen in DP-MSCs while BM-MSCs were well differentiated. Our findings were agree with those of Gronthos et $\mathrm{al}^{2}$, who expanded DP-MSCs from single-cell clones and demonstrated that they exhibited osteogenic differentiation and did not form lipidladen adipocytes. During osteogenic cell differentiation, the markers of the undifferentiated cells are gradually turned off, and the differentiation markers are sequentially expressed. We observed the sequential secretion of proteins at the end of the assay, in which the ON levels decreased in the T.spicata var. intricata-treated group compared to the control group. ON is an early marker of osteogenesis that is synthesized by preosteoblasts and has less affinity to collagen. The ON transcript is quite stable, with a half-life of $>24$ hours under conditions of transcription arrest ${ }^{16}$. The T. spicata var. intricata-treated DP- and BM-MSCs exhibited higher OCN levels than the untreated DP- and BM-MSCs. We suggest that T. spicate var. intricata accelerates the differentiation of MSCs. Therefore, $T$. spicata var. intricata could be a safe inducer for both healthy and medically compromised patients.

Both IL-6 and IL-10 were present in the DP- and BM-MSCs cell culture supernatants ${ }^{4}$. Our results showed that when the extract used alone the IL-6 level was increased in BM-MSCs while it was decreased in DP-MSCs. On the other hand in contrast with this result, the DP-MSCs were pretreated with $T$. spicata var. intricata, before TNF- $\alpha$ stimulation the IL-6 level decreased at a ratio of $94 \%$ and $42 \%$ in DPMSCs and BM-MSCs respectively. This result raise the possibility that the number of IL-6 receptor on cell membrane may be important factor controlling the IL-6 response in target tissues in physiological or pathological conditions. In similar with our results some reports suggested that when soluble IL-6 receptor is available, IL-6 additionally acts on osteoblasts to induce their differentiation ${ }^{17}$. Increased ostegenic activity could be linked to the induced IL-6 activity in BM-MSCs. IL-6 is a multifunctional cytokine that regulates pleiotropic functions of cells and tissues ${ }^{18}$. Reduced IL-6 in response to TNF- $\alpha$ showed that $T$. spicata var. intricata could be a well immunomodulatory agent in inflammatory cnditions. There have been many reports which suggest that IL-6 plays an important role in osteoclastic bone 
resorption in vitro as well as in vivo ${ }^{19}$. According to our results and the reported data a coculture study with osteoblasts and osteoclast treated with $T$. spicata var. intricata should be done.

Here we demonstrated a $T$. spicata var. intricata extract can induce osteogenic differentiation, and modulate the immune responses of DP-MSCs and BM-MSCs. To introduce a new material to be used as a new scaffold in bone regeneration cell growth properties and osteogenic stimulation potency should be determined, and in vitro cell culture studies are required to cary the new material to the stage of animal studies. T. spicata var. intricata could be a promising osteogenic inducer in dentistry and could be used safely in biocomposites or scaffold fabrications.

\section{ACKNOWLEDGEMENT}

This study was supported by the Turkish Scientific and Technological Research Council (TUBITAK), Project no: SBAG 113S448. We specially thank to Prof. Dr. Petek Korkusuz and Sevil Köse for assistance in xCELLıgence assays and analysis.

\section{CONFLICT OF INTERESTS}

Authors declare that there is no conflict of interests.

\section{REFERENCES}

1. Estrela C, Alencar AHGD, Kitten GT, Vencio EF, Gava E. Mesenchymal stem cells in the dental tissues: perspectives for tissue regeneration. Braz Dent J. 2011; 22: 91-8.

2. Gronthos S, Mankanı M, Brahım J, Robey PG, Shı S. Postnatal human dental pulp stem cells (DPSCs) in vitro and in vivo. Proceed Nat Acad Sci. 2000; 97: 13625-30.

3. Hoiruchı K, Amızuka N, Takeshita S, Takamatsu H, Katsuura M, Ozawa H, Toyama Y, Bonewald LF, Kudo A. Identification and chracterization of a novel protein, perostin, with restricted expression to periosteum and periodontal ligament and increased expression by transforming growth factor beta. J Bone Miner Res. 1999; 14: 1239-49.

4. Egermann M, Goldhahn J, Schneider E. Animal models for fracture treatment in osteoporosis. Osteoporos Int. 2005;16 (suppl2): 129-38.

5. Tanker M, Ilisulu F. Thymbra spicata L. var. spicata: one of the plants used in Turkey as thyme. Turk J Bot. 1984; 8: 104-108.

6. Akkol EK, Avci G, Kucukkurt I, Keles H, Tamer U, Ince S, Yeşilada, E. Cholesterolreducer, antioxidant and liver protective effects of Thymbra spicata L. var. spicata. J Ethnopharmacol. 2009;126: 314-9.

7. Chami F, Chami N, Bennis S, Trouillas J, Remmal A. Evaluation of carvacrol and eugenol as prophylaxis and treatment of vaginal candidiasis in an immunosuppressed rat model. $\mathrm{J}$ Antimicrob Chemo. 2004; 54: 909-14.

8. Landa P, Kokoska L, Pribylova M, Vanek T, Marsik P. In vitro anti-inflammatory activity of carvacrol: inhibitory effect on COX-2 catalyzed prostaglandin E(2) biosynthesis. Arch Pharm Res. 2009; 32: 75-8.

9. Baser KHC. Her Derde Deva Bir Bitki-Kekik. Bilim ve Teknik. 2001;74: 4

10. Kizil S. Determination of essential oil variations of Thymbra spicata var. spicata L. naturally growing in the wild flora of East Mediterranean and Southeastern Anatolia regions of Turkey. Indust Crops and Prod. 2010;32: 593-600.

11. Chai YC, Roberts SJ, Schrooten J, Luyten FP. Probing the osteoinductive effect of calcium phosphate by using an in vitro biomimetic model. Tiss Eng Part A. 2011; 17: 1083-97.

12. Roche Diagnostics. GmbH.Introduction of the RTCA SP Instrument. RTCA SP Instrument Operator's Manual, A.Acea Biosciences, Inc ; 2008; 14-16.

13. Pittenger MF, Mackay AM, Beck S. Multilineage potential of adult human mesenchymal stem cells. Sci. 1999; 284: 1168-70.

14. Hensten-Pettersen A. Comparison of the methods available for assessing cytotoxicity. Int Endod J. 1988;21: 89-99. 
15. D'aquino R, Grazıano A, Sampaolesı M, Laino G, Pirozzı G, De Rosa A, Papaccio G. Human postnatal dental pulp cells co-differentiate into osteoblasts and endotheliocytes: a pivotal synergy leading to adult bone tissue formation. Cell Death Differ. 2007; 14: 116271.

16. Dole NS, Kapınas K, Kessler CB, Yee S, Adams JD, Pereira RC, Delany AM. A single nucleotide polymorphism in osteonectin 3 ' untranslated region regulates bone volume and is targeted by miR-433. J Bone and Mineral Res. 2015; 30: 723-32.

17. Ishihara K, Hirano T. IL-6 in autoimmune disease and chronic inflammatory proliferative disease. Cytokine Growth Factor Rev. 2002; 13:357-68.

18. Taga T, Kishimoto T. Role of a two-chain IL-6 receptor system in immune and hematopoietic cell. Crit Rev Immunol. 1992;11:265-80.

19. Roodman, GD. Interleukin 6: an osteotropic factor?. J. Bone Miner Res. 1992;7:475-8.

Received: February 03, 2016; Accepted: July 14, 2016 